DOI: 10.32844/2222-5374-2020-104-2.17

УДК: 351.74; 342

Іваниця А. В.,

доцент кафедри загальноправових дисциплін

Дніпропетровського державного університету внутрішніх справ, кандидат юридичних наук, доцент

\title{
ДО ПИТАННЯ ПРО СПЕЦИФІКУ ПРОФЕСІЙНОЇ ОРІЄНТАЦІЇ ПОЛІЦЕЙСЬКИХ В УКРАЇНІ
}

Актуальність статті полягає в тому, що сучасні конкурентоздатні економіки передових країн світу характеризуються високою мобільністю населенняусферіринкупраці, державиприділяютьзначноїувагимоніторингу відповідних потреб у професіях, запитах суспільства, вибудовують багаторічні плани. В сучасних умовах забезпечення Національної поліції України високоякісними кадрами окрім цілого комплексу умов, підходів та заходів, неможливе в тому числі без побудови системи професійної орієнтації молоді та інших категорій населення щодо професії поліцейського. Слід зауважити, що помилково вважати надання, наприклад, школярам чи студентам цивільних вузів загальної інформації про службу в поліції, вимоги до поліцейських та рівень заробітних плат, основним аспектом профорієнтаційної роботи. Дане явище складається із цілого комплексу елементів, до яких входить і виявлення потенційно значущих високоякісних кадрів серед молоді для служби в поліції, а також прощес адаптації поліщейського на службі тощо. Без врахування сутності явища професійної орієнтації неможливо побудувати ефективну систему залучення та відбору кадрів поліції, й навпаки ефективна організація профорієнтації забезпечить високий рівень якостей та характеристик, необхідних для служби серед осіб, які бажають стати поліщейськими, під час вже відбору кадрів. В статті розриваються проблеми визначення сутності професійної орієнтації молоді тарізноманітнихкатегорійнаселення, а також особливостейданогопроцесу щодо професії поліщейського. Наводяться погляди різноманітних дослідників на формулювання дефініції «професійна орієнтація». Вказується, що не зважаючи на значну кількість різноманітних трактувань та визначень, в цілому зміст явища є схожим. Окрім того, в дослідженні наводяться думки спеціалістів про елементи професійної орієнтації (професійна інформація, професійна консультація, професійний відбір, професійний добір, професійна адаптація), зазначається на відмінностяху кількості елементіву порівнянні із визначеними у нормативно-правових актах (Положення про професійну орієнтацію молоді, яка навчається, Положення про організацію професійної орієнтації населення, Концепція державної системи професійної орієнтації населення, Закон України «Про зайнятість населення»). Акцентується увага, що й у нормативних актах не існує єдиного сталого визначення професійної орієнтації. Визначаються також основні завдання, які ставляться перед професійною орієнтацією молоді та інших категорій населення, на відмін- 
ностях між ними у різних нормативних актах. Зауважується на специфіці визначення, учасників процесу (суб'єктів і об'єктів) професійної орієнтації, яка здійснюється щодо професії поліцейського.

Ключові слова: Національна поліція, молодь, професійна орієнтація, професійна інформація, професійна консультація, професійний відбір, професійна адаптація.

Актуальність теми. Сучасні конкурентоздатні економіки передових країн світу характеризуються високою мобільністю населення у сфері ринку праці, держави приділяють значної уваги моніторингу відповідних потреб у професіях, запитах суспільства, вибудовують багаторічні плани. В сучаснихумовахзабезпечення НаціональноїполіціїУкраїни високоякісними кадрами окрім цілого комплексу умов, підходів та заходів, неможливе в тому числі без побудови системи професійної орієнтації молоді та інших категорій населення щодо професії поліцейського. Слід зауважити, що помилково вважати надання, наприклад, школярам чи студентам цивільних вузів загальної інформації про службу в поліції, вимоги до поліцейських та рівень заробітних плат, основним аспектом профорієнтаційної роботи. Дане явище складається із цілого комплексу елементів, до яких входить і виявлення потенційно значущих високоякісних кадрів серед молоді для служби в поліції, а також процес адаптації поліцейського на службі тощо. Без врахування сутності явища професійної орієнтації неможливо побудувати ефективну систему залучення та відбору кадрів поліції, й навпаки ефективна організація профорієнтації забезпечить високий рівень якостей та характеристик, необхідних для служби серед осіб, які бажають стати поліцейськими, під час вже відбору кадрів. Тому відповідна проблематика на даний момент є достатньо актуальною.

Стан дослідження. До наукового доробку 3 проблематики дослідження питань профорієнтаційної роботи у правоохоронних органах дослідники, а також поліцейські-управлінці як: Барко В., Головіна I., Швець Д. та інші.

Метою статті є аналіз сутності професійної орієнтації, особливостей профорієнтації поліцейських.

Виклад основного матеріалу. Варто зауважити на слушності розкриття питання дефініції «професійної орієнтації» у існуючих нормативно-правових актах, а також серед українських науковців, її структурні елементи, завдання тощо.

У підручнику «Професійна орієнтація» за редакцією О. Ігнатович професійна орієнтація вказується як: «...комплекс науково-обгрунтованих форм, методів та засобів допомоги особистості щодо вибору чи зміни професії, працевлаштування на основі врахування її індивідуальнопсихологічних особливостей, інтересів, можливостей та потреб ринку праці в кадрах» [8 с. 23]. А спрямована вона зближення професійних інтересів молоді та існуючих потреб ринку. Структурно виділяються три елементи або технологічні складові функціонального змісту професійної орієнтації - професійну інформацію, професійну консультацію й професійний відбір або добір, а науково-методичними засобами профорієнтації виступають професіографія та психодіагностика [8, с. 23]. 
Т. Ананко в свою чергу зауважує, професійна орієнтація є науковопрактичноюсистемоюпідготовкиособистості до свідомогосамовизначення подальшої професії, й це самовизначення відповідає потребам суспільства та особливостям відповідного індивідуума. Дослідниця зауважує, що протягом тривалого часу професійна орієнтація розглядалася у вузькому сенсі й не відображала усієї широти змісту даного явища оскільки їі сприймали суто як шкільний аспект в контексті загальноосвітнього процесу [5]. Т. Ананко наводить визначення профорієнтації інших дослідників, наприклад Янцура М.: «Професійна орієнтація - це система, яка забезпечує підготовку учнів загальноосвітніх навчальних закладів до оптимального вибору професії, професійного навчання та визначення напрямів професійної діяльності» [5, с. 26]; Пряжникової Є.: «Професійна орієнтація - це цілісна система, яка складається із взаємопов'язаних компонентів, об'єднаних загальною метою i єдністю управління: професійна просвіта, розвиток інтересів, схильностей школярів у різних видах діяльності - ігровій, пізнавальній трудовій (професійна активізація), професійна психодіагностика, професійна консультація, професійний відбір, професійна адаптація і професійне виховання» [5, с. 27-28].

Дослідниця також вказує на три структурні елементи профорієнтації, зазначає, що вони суттєво взаємопов'язані й часто неможливо на практиці встановити між ними межі. Професійна інформація виступає окремим самостійним (відносно) елементом як система організації та проведення навчальної та виховної роботи, яка спрямована на засвоєння необхідних знань про психологічні та психофізіологічні умови правильного вибору професії. Метою консультації $є$ встановлення гармонізації особливостей індивідуальних, психологічних та особистісних майбутнього працівника відповідно до специфіки тієї або іншої професії. Слід зауважити, що даний компонент у світлі суттєвої специфіки режиму роботи, впливу на психологічний стан особи тощо в роботі у поліції $€$ суттєвим та важливим під час проведення серед школярів та молоді профорієнтаційної роботи [5, с. 28-29]. Професійні консультації поділяються на довідкові (молодь дізнається про вимоги прийняття на роботу, наприклад, вимоги до фізичного рівня, освіти патрульного поліцейського, керівного складу тощо), діагностичні, які вивчають особу, її інтереси й здібності для того щоб виявити найбільш придатну для неї професію, формуючі (керівництво щодо корекції вибору професії), медичні (наприклад, з'язування рівня придатності здоров'я школяра до служби у поліції).

До речі, В. Лозовецька щодо професійної консультації зауважує, люди, які знаходяться перед вибором професії, мають особливий психологічний настрій для самопізнання. У них $є$ прагнення розібратися в собі, оцінити свої можливості, дізнатись про умови, що сприятимуть або заважатимуть входженню до світу професії. Найбільш чутливими у плані розвитку професійної самосвідомості характеризуються особи на етапах старшого шкільного та юнацького віку. Тому в умовах професійного консультування, в тому числі й з приводу професії поліцейського, поряд із використанням класичних підходів та методик (які вивчають особистісні характеристики, інтереси, здатності та схильності особи), необхідно приділити увагу методикам, які досліджують самосвідомість й самооцінку особи [7, с. 25]. 
Професійний відбір здійснюється вже поза школою, а його метою $є$ виявлення рівня придатності особи до конкретного специфічного типу праці. Профвідбір відбувається вже із перевагою щодо претендентів, які володіють певним рівнем професійно важливих якостей, які забезпечать перспективність особи розвиватись. Слід зауважити, що Т. Ананко називає ще професійну адаптацію кінцевим етапом професійної орієнтації, й визначає його як активний процес пристосування особи до нового професійного оточення, умов праці й особливостей конкретної спеціальності, й від успішності адаптації залежить, чи залишиться особа у відповідній професії та чи буде в подальшому займатись розвитком характеристик, необхідних для професійної діяльності [5, с. 29].

В. Лозовецька говорить про безліч наявних визначень профорієнтації, як приклад, вказує на Зеера Е., який наводить декілька тлумачень даної дефініції (як система науково обгрунтованих психолого-педагогічних та медичних заходів, які спрямовані на підготовку молоді в питаннях їх вибору професії, 3 врахуванням їх особистісних особливостей та відповідниї потреб суспільства; обгрунтований науково розподіл людей за різними родами професійної діяльності, що пов'язається із суспільними потребами в професіях та придатністю осіб до видів такої діяльності; а також профорієнтація розглядається як сукупність психологічних й педагогічних заходів та комплексу інформації, що спрямовані вплинути на прийняття рішення щодо оволодінням оптантом певної професії/ спеціальності [7, с. 9].

В свою чергу у нормативно-правових актах застосовуються дещо різні за формулюванням, однак схожі за змістом дефініції «професійної орієнтації». Наприклад у Положенні про професійну орієнтацію молоді, яка навчається від 2 червня 1995 р. [4] вказується в пункті 1 Розділу I: «професійна орієнтація - це комплексна науково обгрунтована система форм, методів ізасобів, спрямованих на забезпечення допомоги особистості в активному свідомому професійному самовизначенні та трудовому становленні» [4]. Відповідно, основною професійного самовизначення тут вказується самопізнання та об’єктивна самооцінка своїх особливостей, співставлення професійних якостей та можливостей 3 відповідними вимогами, які ставляться перед певною професією, та кон'юктурою ринку праці. Слід зауважити, що на відміну від думки деяких науковців, згаданих вище, в даному нормативно-правовому акті вказані наступні елементи професійної орієнтації: професійна інформація, консультація, добір, відбір, а також адаптація.

В цьому ж 1995 році було затверджене Положення про організацію професійної орієнтації населення, себто дане положення розширювало коло суб'єктів процесу професійної орієнтації вказано дещо інше формулювання професійної орієнтації, які в цілому відповідає тому, що зазначено в пункті 1.4. 1 Розділу Положення про профорієнтацію молоді: «Професійна орієнтація населення - це комплексна науково-обгрунтована система форм, методів та засобів впливу на особу з метою оптимізації іiї професійного самовизначення на основі врахування професійно важливих особистісних характеристик кожного індивідуума та потреб ринку праці» [3]. Тут також вказані спрямованість професійної орієнтації - до- 
сягнути балансу між професійними інтересами й можливостями людини та потребами суспільства в конкретних професіях. Окрім того, професійна орієнтація сприяє не лише розвитку здібностей людини, зазначається в Положенні, а також зростанню професіоналізму, працездатності, а також збереженню здоров'я. Профорієнтація вказується важливим елементом політики держави, що сприяє ефективному використанню трудового потенціалу громадян. Метою профорієнтації зазначається сприяння різними методами підвищувати конкурентоздатність працівника на ринку праці й досягнення зайнятості населення [3]. Тобто, профорієнтація для населення має дещо іншу специфіку щодо дорослих у порівнянні із профорієнтацією школярів.

У Концепції державної системи професійної орієнтації населення, затвердженої 2008 р. [2], надано ще одне трактування профорієнтації: «... $\epsilon$ науково обгрунтованою системою взаємопов>язаних економічних, соціальних, медичних, психологічних і педагогічних заходів, спрямованих на активізацію процесу професійного самовизначення та реалізації здатності до праці особи, виявлення ії здібностей, інтересів, можливостей та інших чинників, що впливають на вибір професії або на зміну виду трудової діяльності» [2].

Окрім Положень та концепцій визначення професійної орієнтації міститься в Законі України «Про зайнятість населення 2012 року [1]. Розділ V тут має назву Професійна орієнтація та професійне навчання. В статті 32 даного Розділу визначення збігається цілком із тим, що наведено в Концепції, однак якщо там вказано про профорієнтацію як науково обгрунтовану систему заходів, то в Законі вказується просто як комплекс взаємопов'язаних економічних та інших заходів. Пунктом 2 статті 32 Закону встановлюються інстанції, які можуть здійснювати професійну орієнтацію щодо населення: заклади освіти, охорони здоров'я, установи, що займаються реабілітацією, медико-соціальними експертними комісіями, територіальними органами центральних органів виконавчої влади (які займаються державною політикою у сфері зайнятості), центрами профорієнтації, молодіжними центрами праці, військовими комісаріатами, установами з виконання покарань, а також підприємствами, установами та організаціями незалежно від форми власності, діяльності та господарювання, однак які займаються наданням послуг профорієнтації [1].

На відміну від Положення про професійну орієнтацію молоді, яка навчається, в статті 33 пунктом першим встановлений інший перелік елементів професійної орієнтації. Якщо особи звернулись до територіальних органів виконавчої влади, які займаються сферою зайнятості населення, то профорієнтація здійснюється за допомогою професійного інформування («...полягає у наданні відомостей про трудову діяльність та іiі роль у професійному самовизначенні особи, інформації про стан ринку праці, зміст та перспективи розвитку сучасних професій і вимоги до особи, форми та умови оволодіння професіями, можливості професійно-кваліфікаційного і кар'єрного зростання, що сприятиме формуванню професійних інтересів, намірів та мотивації особи щодо обрання або зміни виду трудової діяльності, професії, кваліфікації, роботи» [1]); професійного консультування (...спрямованого на оптимізацію професій- 
ного самовизначення особи на основі виявлення їі індивідуально-психологічних характеристик, особливостей життєвих ситуацій, професійних інтересів, нахилів, стану здоров'я та з урахуванням потреби ринку праці» [1]); а також проведення професійного відбору (встановлення відповідності якостей особи щодо певних професій та посад).

Звісно, професійна орієнтація, яка здійснюється Національною поліцію, має власні особливості. Деякі вчені називають професійну орієнтацію в органах внутрішніх справ України системою форм та методів, а також засобів впливу на особистість, яка заснована на науковому обгрунтуванні та має на меті формувати та оптимізувати професійне самовизначення, а також збалансування професійних інтересів та можливостей особи враховуючи потреби системи органів внутрішніх справ [6, с. 185]. Натомість Д. Швець наводить дещо інше формулювання: «Професійна орієнтація на службу в правоохоронних органах України - це комплексна науково обгрунтована система форм, методів і засобів впливу на особу з метою формування й оптимізації іï професійного самовизначення, що базується на основі врахування професійно важливих особистісних характеристик, потреб кадрового забезпечення відповідних органів і підрозділів» [9, с. 77].

Завданнями професійної орієнтації, наприклад у Положенні про професійну орієнтацію молоді, постають: ознайомлення учнів і вихованців з різноманітними існуючими професіями, правилами, яких слід дотримуватись під час обрання професії; виховувати у молоді прагнення до самопізнання й власну активність в якості основи професійного самовизначення; формувати здатність у молоді порівнювати власні якості та здібності із тими вимогами, які необхідні для набуття професії, складання плану оволодіння професією; забезпечення розвитку у молоді тих якостей, які необхідні для професії. Серед функцій зазначаються соціально-економічна, медико-фізіологічна, психолого-педагогічна [4].

Натомість в Положенні про організацію професійної орієнтації населення наведено розширений перелік завдань профорієнтаціє: забезпечення права громадян на працю, конкурентоздатності особи на ринку працевлаштування, вільного вибору професії, зміни професії, тощо; підвищення мобільності особи на ринку праці, збереження її здоров'я і працездатності; сприяти гармонійному розвитку особи, ефективності її професійного становлення; стимулювання ініціативи особи у економічній та соціальній сферах, інтелектуального потенціалу; забезпечувати комплексний підхід до роботи щодо професійної орієнтації; формувати правові, соціально-економічні та інші засади розвитку профорієнтації населення; розробка нових форм профорієнтаційної роботи з населенням; розробка нормативно-правових документів необхідних для врегулювання питань профорієнтації; вдосконалення існуючої структури управління профорієнтацією; організація міжнародного співробітництва задля обміну досвідом [3].

В питаннях професійної орієнтації в Національній поліції, слід зауважити, що об’єктами орієнтації постають громадяни України, особливо учнівської молоді та юнаків, які або мають наміри служити в Національній поліції, або підходять за вимогами до такої специфічної 
професії; військовослужбовці, нацгвардійці або працівники поліція, які бажають навчатись у 3В0 із специфічними умовами навчання при MBC України. Натомість професійною орієнтацією займаються органи а також підрозділи поліції, відомчі 3ВО, спеціально створені установи, що займаються профорієнтацією населення; новим явищем для України $\epsilon$ рекрутингові центри при Національній поліції [9, с. 77].

Висновки. Отже, на даний момент існує безліч різних визначень дефініції «професійна орієнтація» серед науковців. У нормативно-правових актах також містяться різні трактування даного терміну, однак, в цілому, вони збігаються за змістом даного явища. Необхідно зауважити, що в нормативно-правовихактах існує різне трактування елементів професійної орієнтації. В цілому слід зауважити, що профорієнтація у поліції має власні суттєві особливості в питаннях учасників таких відносин, як суб'єктів, так і об’єктів. Необхідно зауважити, що профорієнтацією окрім інстанцій Національної поліції, суттєво займаються відомчі навчальні заклади. Вважаємо за необхідне наголосити на необхідності суттєвого акцентування уваги під час проведення професійної орієнтації на такі складові, як професійна консультація та адаптація, оскільки перша дозволить виявити потенціальні ефективні кадри для поліції, а друга швидше пристосуватись особі на новому поприщі.

\section{СПИСОК ВИКОРИСТАНИХ ДЖЕРЕЛ}

1. Про зайнятість населення: Закон України від 5 липня 2012 року № 5067-VI. URL: https://zakon.rada.gov.ua/laws/show/5067-17

2. Концепція державної системи професійної орієнтації населення: постанова Кабінету Міністрів України від 17 вересня 2008 р. № 842.

3. Положення про організацію професійної орієнтації населення: Наказ Міністерства праці України, Міністерства освіти України та Міністерства соціального захисту населення України № 27/169/79 від 31 травня 1995 р.

4. Положення про професійну орієнтацію молоді, яка навчається: Наказ Міністерства освіти України, Міністерства праці України і Міністерства у справах молоді і спорту України від 2 червня 1995 року № 159/30/1526.

5. Ананко Т. В. Професійна орієнтація у системі підготовки учнів загальноосвітніх навчальних закладів України до професійної діяльності. Теоретико-методичні проблеми виховання дітей та учнівської молоді. 2014. Вип. 18(1). С. 25-33.

6. Барко В. І., Головіна I. Ф. Напрями вдосконалення професійної орієнтації молоді на професії органів внутрішніх справ України. Вісник Національного університету оборони України. 2013. 1 (32). С. 185-189.

7. Лозовецька В. Т. Професійна орієнтація молоді в умовах сучасного ринку праці : монографія. К.: ІПТО НАПН України, 2012.157 с.

8. Професійна орієнтація : підручник [для студентів] / Єгорова Є.В. та ін.; за ред. О.М. Ігнатович. Кіровоград : Імекс-ЛТД, 2014. 240 с.

9. Швець Д.В. Особливості профорієнтаційної роботи та професійного відбору і службу в Національну поліцію України. Підготовка поліцейських в умовах реформування системи МВС України: зб. наук. пр. Харків: ХНУВС, 2019. C. 75-79. 


\section{A. Ivanytsia}

\section{ON THE QUESTION Of THE SPECIFIC PROFESSIONAL ORIENTATION OF POLICE IN UKRAINE}

The relevance of the article is that modern competitive economies of advanced countries are characterized by high mobility of the population in the labor market, states pay considerable attention to monitoring the relevant needs in professions, the demands of society, build long-term plans. In modern conditions, providing the National Police of Ukraine with high-quality personnel, in addition to a range of conditions, approaches and measures, is impossible, including without building a system of vocational guidance for young people and other categories of the population in the police profession. It should be noted that it is wrong to consider, for example, the provision of general information on police service, requirements for police officers and the level of salaries to schoolchildren or students of civil universities as a key aspect of career guidance work. This phenomenon consists of a whole set of elements, which include the identification of potentially significant high-quality personnel among young people for service in the police, as well as the process of adaptation of the police officer in the service and so on. Without taking into account the essence of the phenomenon of career guidance, it is impossible to build an effective system of recruitment and selection of police personnel, and conversely, effective career guidance will provide a high level of qualities and characteristics necessary for service among those wishing to become police officers. The article deals with the problems of determining the essence of the professional orientation of young people and various categories of the population, as well as the features of this process regarding the profession of police officer. The views of various researchers on the formulation of the definition of "professional orientation» are given. It is stated that, despite the large number of different interpretations and definitions, the overall meaning of the phenomenon is similar. In addition, the study presents the opinions of professionals about the elements of vocational guidance (professional information, professional advice, professional selection, professional adaptation), noted the differences in the number of elements compared with those defined in the legal acts (the Regulation on the vocational guidance of young people , Regulations on the Organization of the Vocational Orientation of the Population, The Concept of the State System of Vocational Orientation of the Population, the Law of Ukraine "On Employment of the Population»). Attention is drawn to the fact that in the normative acts there is no single permanent definition of professional orientation. It also defines the main tasks that young people and other categories of the population are facing, as well as the differences between them in different regulations. It is noted on the specifics of the definition of participants in the process (subjects and objects) of the professional orientation that is carried out in relation to the police profession.

Keywords: National police, youth, professional orientation, professional information, professional consultation, professional selection, professional adaptation. 